\title{
From European Colony to a New Era: EU-Vietnam Relations - 1990-2017
}

\author{
Hang Thi Thuy Nguyen \\ Diplomatic Academy of Vietnam, Hanoi \\ hangnguyen@dav.edu.vn \\ Bruno Mascitelli \\ Swinburne University of Technology, Melbourne \\ bmascitelli@swin.edu.au
}

\begin{abstract}
In the international relations literature review, there have been voluminous studies on EU-ASEAN relations but only a small number on EU-Vietnam relations. Furthermore, it is obvious that most of studies thus far conducted on EU-Vietnam relations have dominantly addressed trade relations. As the EU and Vietnam have sought to build a comprehensive partnership and cooperation since 2012, it is important to provide an insight into the history of the EU-Vietnam relations in various areas. With this in mind, this paper seeks to examine the past, present and the future of the EU-Vietnam relations which will be thematically divided into two periods: (i) 1990-2005: Befriending; (ii) 2006-present: Strengthening the Friendship. Also, the paper will discuss the future direction for the EU -Vietnam relations. By using content analysis as the main research methodology, the paper has analysed official documents from both European Union and Vietnamese official bodies and scholarly writings to demonstrate that the EU and Vietnam have make a very comprehensive effort to intensify their bilateral relations.
\end{abstract}

Keywords: EU, Vietnam, partnership, the EU-Vietnam free trade agreement, cooperation

\section{Introduction}

Since establishing diplomatic ties in October 1990, the EU and Vietnam have undergone a multidimensional development of their relations. Currently in place and signed in 2012, is a bilateral "Comprehensive Partnership and Cooperation," which is aimed at strengthening the EU-Vietnam bilateral dialogues and cooperation programs. Especially, with the conclusion of the EU-Vietnam Free Trade Agreement in 2016 the EU-Vietnam bilateral relations have been quickly expanded so that they now include trade, environment, energy, science and technology, good governance, human rights as well as tourism, culture, migration and the fight against corruption and organised crime. To emphasise the ever increasing level of bilateral trade, in 2016 the EU was Vietnam's third biggest trading partner (after China and the U.S.) and the second top export market for Vietnam's products. Yet, there has been surprisingly little research on the EU-Vietnam comprehensive partnership. This paper seeks to fill this gap by providing an insight into the history of the relations between the EU and Vietnam since 1990. The paper will begin with a brief introduction of the interaction between Europe and Vietnam as early as the $17^{\text {th }}$ century before exploring the main developments in the 
EU and Vietnam relations in modern times (1990-2017) which can be thematically divided into two main stages: (i) 1990-2005: Befriending; (ii) 2006-present: Strengthening the Friendship. Last but not least, the paper will provide an analysis of the prospects for the EU-Vietnam relations, and put forth recommendations for Brussels and Hanoi to work with each other more effectively for their mutual benefits.

\section{Europe and Vietnam: Early Interactions}

The Europe-Vietnam relations can be traced back to as early as the $17^{\text {th }}$ century when the two different cultures, European and Vietnamese, interacted with each other through European colonial practices. British, Portuguese, Italian, and French missionaries were the very first Europeans to arrive in Vietnam. While the British began formal contact with the Vietnamese in 1613, after remaining for a few years they soon left Vietnam definitively. ${ }^{1}$

In 1615, the first European Jesuits, the Portuguese Jesuits Carvel and Goa Buzoni arrived in Tourane (Đà Nẵng) and established a Jesuit missionary station in Faifo (Hội An). In 1618, an Italian Jesuit, Cristoforo Borri landed in Vietnam,considered one of the European missionaries who sometime in 1620 attempted the Romanisation of the Vietnamese language. ${ }^{2}$ Borri wrote an informal report on the Jesuit mission in Cochinchina (South Vietnam) in the early $17^{\text {th }}$ century in Italian, a report which would also be translated into various European languages. ${ }^{3}$

In 1629 a French Jesuit, Alexandre de Rhodes, came to Vietnam and set up another missionary station in the country. He contributed to the alphabetisation of Vietnamese. In 1651, Alexandre de Rhodes composed a dictionary entitled "Dictionarium and Cathechismus" that listed Vietnamese entry words in alphabetical order. The dictionary which was a lasting success was the product of the early interaction between the Europeans and the Vietnamese. ${ }^{4}$

However, the Vietnamese rulers feared being overrun by Europeans and began banning European missionaries including burning Christian texts and religious books. From 1848 to 1851, the King of Vietnam, Tự Đức (1848-1883) banned all missionary activities in Vietnam and even offered a reward for any killed Europeans. Tự Đức's hostility to European missionaries triggered a violent response from French Emperor Napoleon III. In 1858, France sent its military forces to Tourane (Đà Nẵng) and began the conquest of South Vietnam. In 1867, South Vietnam fell under French control and France took complete control of Central and North Vietnam by the mid-1880s. ${ }^{5}$

\footnotetext{
${ }^{1}$ Alastair Lamb. 1970. The Mandarin Road to Old Hue Narratives of Anglo-Vietnamese Diplomacy from the 17th century to the Eve of the French Conquest, London: Archon Books, p.9.

${ }^{2}$ Peter C. Phan. 2006. Mission and Catechesis: Alexandre de Rhodes \& Inculturation in Seventeenth Century Vietnam, Washington: Orbis Books.

3 Olga Dror \& Keith Weller Taylor. 2006. Views of Seventeenth-century Vietnam: Christoforo Borri on Cochinchina \& Samuel Baron on Tonkin, New York: SEAP Publications.

4 Nguyễn Đình Hòa. 2009. Seventeenth Century Vietnamese Lexicon: Preliminary Gleanings from Alexandre de Rhodes' Writings. Sealang Projects. Accessed on 25 October, 2017,

$<$ http://sealang.net/sala/archives/pdf8/nguyen1991seventeenth.pdf $>$.

5 Nigel Thrift \& Dean Forbes. 2007. The Price of War: Urbanization in Vietnam, 1954-1985, London: Routledge, p. 47.
} 
Vietnam remained a French colony until it gained its independence in 1945. The two Indochina wars (1946-1954 and 1965-1975) and the "bipolarity" of the international system in the Cold War period certainly affected the relationship between the then European Community and Vietnam. In reality, the ideological confrontation was a key factor that hindered Vietnam-Europe relations as most of the European Community's Member States were supportive of US actions and approaches in relation to Vietnam. As such, Vietnam and the European Community had no official connections prior to 1990. With the launch of Vietnam's reform policy (known as Đổi Mới in Vietnamese) in 1986 and the end of the Cold War in 1989, the European Community and Vietnam began to explore the first steps in pursuing diplomatic relations. October 22, 1990, when both sides agreed to form official diplomatic ties, made history as a crucial milestone in EU-Vietnam relations .

\section{0-2005: Befriending Each Other}

In 1990, the European Community and Vietnam officially established diplomatic relations. The early 1990 s was important for Vietnam and the European Community as both sides had recently made decisive changes in policy approaches: Vietnam with economic reform (Đổi Mới) in December $1986 .{ }^{6}$ The European Community with the Single European Act in February $1986 .^{7}$

As for Vietnam, Đổi Mới was a step forward in its economic and political progress. By 1986, the former Party Secretary-General, Trường Chinh, realised that Vietnam's focus on central planning and large-scale production led to various socio-economic problems. He observed that:

...we have made mistakes due to 'leftist infantilism', idealism, and to the contravention of the objective laws of socio-economic development. These mistakes were manifested in the... [emphasis given to] developing heavy industry on a large scale beyond our practical capacity...[maintaining] the bureaucratically centralised mechanism of economic management based on state subsidies with a huge superstructure which overburdens the infrastructure. As a result, we relied mostly on foreign aid for our subsistence. ${ }^{8}$

Đổi Mới was officially adopted by the Sixth Party Congress in December 1986. With Đổi Mới, Vietnam aimed to reduce macroeconomic instability and accelerate economic growth by abolition of the system of aspects of centralised management and state subsidies, and to move toward a multi-sector and market-oriented economy. This formed the foundation for a significant change in Vietnamese defining of national interests and making foreign policy. Put simply, it was important that Vietnam's new foreign policy had to contribute to protecting national security. It was equally important that Vietnam's new foreign policy had to create opportunities for economic development. Vietnam saw the urgent need to engage with the wider world for its national development.

\footnotetext{
${ }^{6}$ Quan Hoang Vuong. 2014. Vietnam's Political Economy in Transition (1986-2016). Accessed on 11 October, 2017. <https://worldview.stratfor.com/the-hub/vietnams-political-economy-transition-1986-2016>.

7 Aaron Schildhaus. 1989. 1992 and the Single European Act. The International Lawyer. Vol. 23, No. 2. pp. 549555 .

8 Trường Chinh. Quoted in Brian Van Arkadie \& Raymond Mallon. 2003. Vietnam: A Tiger in Transition? Canberra: Asia Pacific Press.
} 
As for the European Community, the Single European Act was a turning point in its economic and political integration, paving the way to the signing of the Maastricht Treaty in 1992 that created the European Union. According to Moravcsik the significance of the Single European Act for the European integration process was in:

The European Community (EC) is experiencing its most important period of reform since the completion of the Common Market in 1968. This new impulse toward European integration-the "relaunching" of Europe, the French call itwas unexpected. The late 1970s and early 1980s were periods of "Europessimism" and "Eurosclerosis," when politicians and academics alike lost faith in European institutions. The current period is one of optimism and institutional momentum. The source of this transformation was the Single European Act (SEA). 9

The Single European Act completely removed restrictive practices in areas of private business as well as in the public sector, in order to reach the target of a full single market by 1992. It attempted to increase transparency by giving more powers to the Parliament to propose new laws, and it gave the Parliament the power to veto the admission of new member states. Importantly, the Single European Act laid the foundation for the creation of common European Foreign, Justice and Home Affairs policies leading to a vision of an ever deeper union. ${ }^{10}$

In the 1990s, Vietnam was open to seeking out constructive and friendly relations with numerous countries in the world, and at the same time the European Community actively sought new partners to open its network in Southeast Asia. The European Community was deepening its integration process and also turning to the Asia-Pacific region to look for markets and to cultivate new partnerships. As the European Community and Vietnam were looking forward to trade and investment opportunities in the early 1990s, they also saw greater potential to work together for common achievements. Diplomatic circles in both Vietnam and the European Community made moves to further contacts and to understand each other's interests and perspectives.

Vietnamese and European relations began in the early 1990s with a humanitarian dimension as the European Commission stated that "The international problem of reintegration of the boat people in Vietnam is both a humanitarian problem and a development problem." 11 Bilateral EU cooperation with Vietnam was launched in 1990 with an ambitious European Commission programme of $€ 45$ million to assist Vietnamese refugees' repatriation and help them to re-settle in Vietnam. ${ }^{12}$

It was estimated that in October 1992, over 30,000 Vietnamese refugees repatriated voluntarily. The programme conducted by the European Commission in 18 Vietnamese provinces and cities provided the repatriats with professional training and assistance to further employment and establish small business projects. With this programme,

\footnotetext{
9 Andrew Moravcsik. 1991. Negotiating the Single European Act: national interests and conventional statecraft in the European Community. International Organization. 45: 1, p. 19.

10 Wil James. 2015. Single European Act. CIVITAS Institute for the Study of Civil Society. Accessed on 15 October 2017, <http://civitas.org.uk/content/files/TR.2.SEA_.pdf >.

${ }^{11}$ Michael Hindley. 1996. On the Proposal for a Council Decision Concerning the Conclusion of the Cooperation Agreement between the European Community and the Socialist Republic of Vietnam (COM995)0305-C40384/95-95/o173(CNS)), Accessed on 23 October, 2017,<http://www.europarl.europa.eu/sides/getDoc.do?type $=$ REPORT\&reference $=\mathrm{A} 4-1996-0004 \&$ format $=$ XML\&language $=\mathrm{EN}>$.

12 Delegation of the EU in Vietnam.2016. EU Projects with Vietnam. Accessed on 10 October 2017,

$<$ https://eeas.europa.eu/delegations/vietnam/1898/eu-projects-vietnam_en >.
} 
the European Commission contributed to stemming the flow of Vietnamese asylum seekers and reducing poverty in Vietnamese villages. The refugee repatriation initiative was considered as valuable for further cooperation between the European Community and Vietnam. In 1996, the first meeting of the European Community-Vietnam Joint Commission led to the signing of Framework Cooperation Agreement which became the legal basis for cooperation between the European Community and Vietnam. ${ }^{13}$ According to the European Commission, "...it is extremely important for the EU to develop extensive and diversified relations with Vietnam. Consequently, the cooperation agreement arrives at just the right moment."14

The Framework Cooperation Agreement broadened Vietnam and European Community relations beyond the humanitarian dimension of the early 1990s. Its new aims included (i) improving the conditions and promoting the development of bilateral trade and investment, (ii) assisting the sustainable economic development of Vietnam, (iii) strengthening economic cooperation, and (iv) assisting environmental protection and the sustainable management of natural resources. ${ }^{15}$

With the success of the very first cooperation project on refugee repatriation, and the Framework Cooperation Agreement, the European Community carried out development projects of over $€ 102$ million in Vietnam from 1996 to 2001. These projects focused on the development of Vietnam's rural and mountainous provinces, social sectors, on-going economic and administrative reforms, and trade and investment. ${ }^{16}$ Noticeably, the first Country Strategy project with a value of $€ 162$ million for the 5-year period (2002-2006) was agreed in 2002, aiming at poverty reduction, capacity building and supporting Vietnam to integrate into the world economy - for instance joining the World Trade Organisation.

In the economic field, the EU became one of Vietnam's most important trading partners, a main source of foreign direct investment and, especially a main aid donor. The most important outcomes of the EU-Vietnam economic relations during this period included the EU's granting to Vietnam the "most favoured nation" status and tariff preferences under the EU's Generalized System of Preferences mechanism. Trans-regional cooperation was also expanded with the launch of the EU-ASEAN Trade Initiative and the Regional EU-ASEAN Dialogue Instrument in 2003. These two multilateral frameworks enabled the EU and Vietnam to promote their economic and trade cooperation and to maintain dialogue.

In the diplomatic and political field, the frequency of high-level meetings and exchanges between the EU and Vietnam increased. The first EU-Vietnam Summit was held in Hanoi in 2004. ${ }^{17}$ In the same year, the Vietnamese Party leader, Nông Đức Mạnh paid an official visit to the European Commission and the then President of the European Commission, Romano Prodi and Trade Commissioner Pascal Lamy, replied

\footnotetext{
${ }^{13}$ Ibid.

${ }^{14}$ Ibid.

15 The Council of the European Union. 1996. Council decision of 14 May 1996 concerning the conclusion of the Cooperation Agreement between the European Community and the Socialist Republic of Vietnam. Accessed on 14 October 2017, <http://eeas.europa.eu/archives/delegations/vietnam/documents/eu vietnam/frameworkcooperation agreement en.pdf $>$.

16 Ibid.

${ }_{17}$ European External Action Service. 2017. Chronology of Bilateral Relations. Accessed on 19 October 2017,

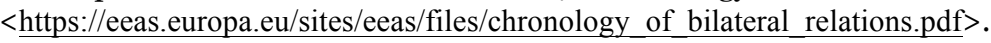


with a follow up working visit to Vietnam. Addressing the European Chamber of Commerce in Vietnam, EC Trade Commissioner Pascal Lamy underlined that:

Vietnam's Eurocham is a demonstration of one of the most successful experiences of European business associations in Asia. Its strong European Union business identity and united voice continue to be essential elements in ensuring that European and Vietnamese businesses develop ever closer ties. The impressive turnout here today is a reflection of Eurocham's capacity to act as the focal point for the EU business community in Vietnam. The EU continues to be the main investor in Vietnam. This provides us with significant leverage with which to promote our interests, while at the same time permitting us to assist Vietnam in achieving its own potential. ${ }^{18}$

These frequent visits and meetings helped both sides to develop mutual understanding and trust and laid the basis for further discussions over issue resolution related to human rights, democracy promotion, and freedom of religion.

No doubt, in the first period of their relationship, Vietnam and the European Community concentrated on development and humanitarian cooperation. The European Community realized Vietnam's need for development aid and was willing to enhance its cooperation with Vietnam by providing such aid through various projects and programmes. The European Community's development assistance for Vietnam and Vietnam's own efforts and strategies to improve its economic conditions helped Vietnam to achieve important progresses in social and economic infrastructure development. Cooperation between them expanded to include job creation in rural towns, empowerment of women, health and education.

\section{6-Present: Strengthening the Friendship}

In the second period of the formal Vietnam-EU relationship, there were more focused changes in the substance of the relations. The Vietnamese economy began to grow rapidly with growth rates exceeded only in China, promising greater access and opportunities to the Vietnamese people. This transformation reflects the success of Đổi Mới and Vietnam's attempts at international integration. Henceforth, trade became far more important than aid in Vietnam's relations with the European Union. The European Union and Vietnam have sought to bring opportunities for European businesses based in Vietnam and for those willing to establish new businesses in Vietnam. Equally, the European Union has opened its market to Vietnamese commodities and services. This underlined the European Union's commitment to supporting Vietnam's reform process and Vietnam's stronger integration into the global trading system. For instance, the European Union' project, the Multilateral Trade Policy Assistance Programme (MUTRAP) has been implemented in Vietnam successfully since 1998. In phase III (2008-2012), the MUTRAP project sought to enhance the capacity of Vietnam's Ministry of Industry and Trade and develop

\footnotetext{
18 Pascal Lamy. 2004. "EU-Vietnam: A Partnership of Equals.” Accessed on 18 October 2017, <http://trade.ec.europa.eu/doclib/docs/2004/october/tradoc_119406.pdf>.
} 
Vietnam's integration strategy into multilateral networks, particularly ASEAN and WTO based on the provision of European experiences. ${ }^{19}$

Besides, the European Trade Policy and Investment Support Project (EU-MUTRAP) which is around 16.5 million euro (EU contribution of 15 million euro) has been implemented between 2012 and 2018. This project is also hosted by Vietnam's Ministry of Industry and Trade. One of the main aims of this project was to boost EU-Vietnam trade and investment relations:

1. EU-Vietnam trade and investment relations are strengthened through enhanced dialogue and co-operation, and the negotiation and implementation of a future EU-Vietnam FTA;

2. The institutional capacity for the negotiation and implementation of multilateral, regional and sub-regional trade commitments is strengthened;

3. Investment policy frameworks are improved, with a particular focus on the environmental and social issues in trade and investment related policies and legislation;

4. The access to information, regulations and market opportunities relative to Vietnam's international trade and investment commitments is improved; with increased stakeholder participation in the trade and investment policy development process; and enhanced capacity among SMEs to comply with European market access requirements; and

5. EU-VN dialogue in economic areas of the Framework Agreement on Comprehensive Partnership and Cooperation (PCA) is supported; and flexible assistance is provided to address important, urgent trade issues. ${ }^{20}$

With the shared vision of trade promotion, prosperity and sustainable development, Vietnam and the EU have coordinated to enhance their bilateral trade and investment relations. Bilateral trade between the EU and Vietnam is complementary. The EU mainly exports high tech products (electrical machinery and equipment, aircraft, vehicles, and pharmaceutical products) to Vietnam while Vietnam exports agricultural and fishery products to the EU. ${ }^{21}$ Until mid-2012, 20 out of 27 EU Member States invested in Vietnam with 1,188 valid projects with a total registered capital of more than US $\$ 18$ billion. Vietnamese businesses also invested in about 12 EU Member States (Belgium, Bulgaria, Czech Republic, France, Germany, Greece, Italy, Netherlands, Poland, Spain, Sweden and, U.K) with a total registered capital of $\$ 35.9$ million. ${ }^{22}$ In 2016, the EU was Vietnam's $5^{\text {th }}$ largest foreign investor. 2016 saw a sharp increase in Vietnam-EU trade revenues to over US $\$ 45$ billion from US $\$ 4.1$ billion in $2000 .{ }^{23}$ In the first five months of 2017 , two-way trade was up to US $\$ 19.6$ billion, with Vietnam exporting US $\$ 14.8$ billion of goods to the EU and importing over US $\$ 4.8$

\footnotetext{
${ }^{19}$ Europe Aid \& Ministry of Industry and Trade of Vietnam. 2008. EU-Vietnam MUTRAP III. Accessed on 18 October 2017, <https://www.dmiassociates.com/dmi/EN/eu-vietnam-mutrap-iii >.

${ }^{20}$ European Trade Policy and Investment Support Project. 2017. European Trade Policy and Investment Support Project (EU-MUTRAP), Accessed on 18 October 2017, <http://mutrap.org.vn/index.php/en/about-eu-mutrap$2>$.

${ }^{21}$ European Commission. 2016. European Union, Trade in goods with Vietnam. Accessed on 11 October 2017, $<$ http://trade.ec.europa.eu/doclib/docs/2006/september/tradoc_113463.pdf $>$.

${ }_{22}$ The EU \& Vietnam. 2012. Comprehensive Partnership and Cooperation between the European Union and Its Member States, of the One Part, and the Socialist Republic of Vietnam, of the Other Part. Luck House Graphics. Accessed on 12 October 2017, <http://investmentpolicyhub.unctad.org/Download/TreatyFile/3244>.

23 NDO. 2017. New Impulse for Vietnam-EU Relations. Accessed on 18 October 2017,

<http://en.nhandan.com.vn/business/item/5315002-new-impulse-for-vietnam-eu-relations.html>.
} 
billion of goods from the market. ${ }^{24}$ It is noted that the EU still has a negative balance of trade in goods with Vietnam. In 2016, EU-Vietnam trade in goods reached $€ 42.4$ billion. Of which the EU's exports to Vietnam was worth €9.3 billion while the EU's imports from Vietnam reached $€ 33.1$ billion. $^{25}$

The EU and Vietnam's efforts to enhance their bilateral relations was especially evident in the EU's approach towards Vietnam's poverty reduction, with the philosophy of poverty reduction through trade promotion, the second Country Strategy for another five-year period (2007-2013) ( $€ 298$ million). This builds on the progress of the first Country Strategy and its aim to continue to lift more Vietnamese people out of poverty, in line with Vietnam's Socio-economic Development Plan and the Millennium Development Goals strategy. ${ }^{26}$

Especially, with the Multi-Annual Indicative Programme for Vietnam (2014-2020), the EU pledged to contribute $€ 400$ million to assist Vietnam with developing a sustainable energy sector and strengthening governance and the rule of law. ${ }^{27}$ It is estimated that by 2020 Vietnam may import $35 \%$ of its energy needs which would increase to $56 \%$ by 2030. ${ }^{28}$ As the energy sector is crucial to Vietnam's industrialisation and modernisation, massive investments in Vietnam's energy sector are needed to improve its energy planning, markets, efficiency and productivity and to promote the usage of clean and renewable energies. Moreover, one of the consequences of Vietnam's fast development path is "its substantial governance deficits." 29

Vietnam's socio-political stability has been the major factor underlying its economic achievements however, "accountability, citizen's participation and the legislative and judicial system have progressed at a slower pace." ${ }^{30}$ Vietnam has seen a dramatic growth of civil society organisations, but their operational effectiveness remains fragmented. They have a limited role in enhancing transparency, accountability and policy formulation. These governance deficits have also impacted Vietnam's business environment. State-owned enterprises still dominate in Vietnam and the private sectors have low levels of competitiveness. The EU's Multi-Annual Indicative Programme for Vietnam aims to help Vietnam address these governance challenges and build an industrialised and inclusive economy in Vietnam.

This second period of the EU-Vietnam partnership witnessed the signing of the EUVietnam Free Trade Agreement (EVFTA). In December 2015, after 14 rounds of negotiations over nearly 3 years, President Donald Tusk, European Commission President Jean-Claude Juncker and Prime Minister of Vietnam, Nguyễn Tấn Dũng officially announced the conclusion of the EVFTA. The final text of the EVFTA was published in February 2016. Both Vietnam and the EU expect the EVFTA to be ratified

\footnotetext{
24 Ibid.

25 European Commission. 2017. Vietnam. Accessed on 18 October 2017,

$<$ http://ec.europa.eu/trade/policy/countries-and-regions/countries/vietnam/\#trade-goods_fig >.

${ }^{26}$ United Nation Development Programme. 2015. Country Report: 15 Years Achieving the Vietnam Millennium Development Goals. Accessed on 18 October 2017, <http://www.vn.undp.org/content/dam/vietnam/docs/Publications/Bao\%20cao\%20TIENG\%20ANH\%20-\%20MDG\%202015_trinh\%20TTCP.pdf>.

27 European Union. 2014. EU Cooperation in Viet Nam: An enhanced response to the development challenges: The Multiannual Indicative Programme for Viet Nam 2014 - 2020. Accessed 19 October 2017, <http://eeas.europa.eu/archives/delegations/vietnam/documents/eu_vietnam/20141113_mip_en.pdf $>$, p.5.

28 Ibid, p.4.

${ }^{29}$ European External Action Service. 2014. Multiannual Indicative Programme for Vietnam. Accessed on 18 October 2017, <https://ec.europa.eu/europeaid/sites/devco/files/mip20142020-programming-vietnam20140818-_en.pdf $>$, p.4

30 Ibid, p.4.
} 
in 2018 and enter into force in 2019. The EVFTA is seen as one of the most comprehensive and ambitious trade and investment agreements that the EU has ever concluded with a developing country. It is the second trade deal between the EU and a Southeast Asian country after the EU-Singapore Free Trade Agreement (EUSFTA) signed in 2014. The EVFTA will deepen the trade relations between Vietnam and the EU and Vietnam will have access to a 500 million people market with a total Gross Domestic Product (GDP) of US\$15, ooo billion (accounting for 22\% of global GDP). Meanwhile, EU enterprises will have more chances to penetrate into one of the fastest-growing economies of over 90 million people in Asia. Markus Beyer, Director General of Business Europe commented that "The EU-Vietnam FTA is a very ambitious and positive agreement. We trust the deal will serve as an example for future agreements with other trading partners in the region." 31

Along with intensification of cooperation and coordination through trade and development projects, Vietnam and the EU organised many high-level visits to allow their leaders to meet and deepen the relations. Prime Minister Nguyen Tan Dung visited Brussels in 2006 highlighting the EU's strategic importance to Vietnam. In November 2007, European Commission President Barroso visited Vietnam and during this visit he and Vietnam's Prime Minister Nguyen Tan Dung launched negotiations for the EU-Vietnam Partnership and Cooperation Agreement signed in 2012. The agreement provided a strong political pillar for the EU-Vietnam relationship. In his second visit to Vietnam in 2014, Barroso spoke at a high-level Vietnamese business leaders' lunch and stressed that "this is my second visit to Vietnam as President of the Commission. This is a sign of the interest and attention that we give to Vietnam and to our bonds which have grown stronger and closer in these last years." 32

The relationship between Vietnam and the EU intensified through further official visits from the European Union. This included the visit by President of the European Union, Herman Van Rompuy to Vietnam in 2012. This was the very first visit of an EU President to Vietnam since diplomatic relations were established in 1990. It opened a new page in the EU-Vietnam bilateral relations as Herman Van Rompuy underlined: "The overall assessment of relations is very, very positive. We are going deeper and wider...we are expanding our relations on the political and on the security side." ${ }^{3}$ Recently, in July 2017, a trilateral meeting was held between Donald Tusk, President of the European Council, Jean-Claude Junker, President of the European Commission, and Nguyễn Xuân Phúc, Prime Minister of Vietnam, in Hamburg on the side lines of the G20 Summit.

The fact that the EU has been enlarging has also brought further opportunities for new relationships in the economic and political relations between Vietnam and the EU. Many of these new EU members used to have relationships with Vietnam during the Cold War. The past linkages to some extent presented Vietnam with an opportunity to build better relationships not only with individual Member States but also with the EU as a whole. This is particularly important as there is a large Vietnamese diaspora in

\footnotetext{
${ }^{31}$ European Commission. 2010. Vietnam. Accessed on 18 October 2017, <https://ec.europa.eu/europeaid/countries/vietnam_en>.

${ }^{22}$ José Manuel Barroso. 2014. Speech by President Barroso at the Vietnam High-level Business Leaders' Lunch. Accessed on 18 October 2017, <https://www.denederlandsegrondwet.nl/935300o/1/j9vvihlf299qosr/vjmncasd3jz1?ctx=vguo1axw2znb $>$.

33 Herman Van Rompuy. 2012. Speech of the President of the European Council Herman Van Rompuy at the lunch with EUROCHAM and the European Business Community in Ho Chi Minh City. Accessed 1 November 2017, < europa.eu/rapid/press-release_PRES-12-453_en.pdf>.
} 
Europe; the Vietnamese are one of the largest migrant communities in the majority of the former Soviet Bloc countries. ${ }^{34}$ This "human connection" has served as a bridge between Vietnam and the enlarged EU. Moreover, Vietnam and the EU have actively interacted with each other through their memberships in different regional, transregional and international organisations such as the ASEAN-EU dialogues, the AsiaEurope Meeting, the ASEAN Regional Forum, the United Nations, and the World Trade Organisation.

\section{Shaping a Shared Future}

The EU and Vietnam are expanding their cooperation beyond trade and economic cooperation, into areas such as energy, technology, environment, climate change, tourism, culture, good governance, corruption, human rights, migration, and security. The EVFTA eagerly anticipated by both the EU and Vietnam will secure a better legal framework for EU investors in Vietnam and for Vietnamese exporters to the EU market. As the Asia-Pacific is the most dynamic region in the $21^{\text {st }}$ century, the EU has been investing its time and resources into this part of the world. Meanwhile, Vietnam is seeking to effectively integrate into the world's economy and calling for foreign investments. The EU and Vietnam have the shared views on peace and prosperity for not only their peoples but also for the whole world. This implies that both sides would be able to work more productively in order to prevail over the longer term.

Yet, in order to become true partners, Hanoi and Brussels need to deal with two thorny issues in their relations including trade deficit and human rights concern. The EUVietnam trade relations have been growing. Vietnam sells labour intensive products while the EU provides capital intensive goods. Therefore, direct competition between Vietnam and the EU is quite rare. ${ }^{35}$ Yet, it is noticeable that Vietnam has had surplus in trade with the EU for more than ten years. In 2013, the EU saw a $€ 15.5$ billion deficit in trade with Vietnam. In 2016, the EU recorded a deficit of $€ 23.8$ billion in trade with Vietnam. The long-standing and ever-increasing EU trade deficit reflects the existing barriers to entering the Vietnam market and also the fact that goods from the EU are more expensive for Vietnam to import than those from China and other Asian countries. In order to balance trade between the EU and Vietnam, it is important for the EU to encourage the liberalisation of trade and investment flows in Vietnam. Vietnam can remove tariff and non-tariff barriers to import specific goods, and also remove obstacles to foreign investment, such as burdensome licensing procedures and protection of intellectual property rights.

In addition, after the EVFTA is fully implemented, Vietnamese businesses will most likely have direct competitors on their home territory as more EU enterprises migrate to establish their firms in Vietnam. The EVFTA will make it easier for EU companies, especially from the pharmaceutical, machinery, agricultural, and "green technologies" sectors, to penetrate the Vietnamese market. Similarly, EU businesses have concerns about Vietnam's increased access to the EU market and the increased competition from Vietnamese suppliers of garments, seafood, and furniture which can put price pressure on EU companies. The EVFTA can provide a good foundation for the promotion of

34 Grażyna Szymańska-Matusiewicz. 2015. The Vietnamese Communities in Central and Eastern Europe as Part of the Global Vietnamese Diaspora. Accessed 1 November, 2017, <http://www.ceemr.uw.edu.pl/vol-4-no-1-june2015/editorial/vietnamese-communities-central-and-eastern-europe-part-global>.

35 Damian Wnukowski. 2015. EU-Vietnam Free Trade Agreement: Opportunities and Challenges for European Businesses. Bulletin of the Polish Institute of International Affairs. Accessed on 19 November, 2017 <http://www.pism.pl/files/?id_plik=19053>. 
Vietnamese goods and services in the EU. Thus, with the implementation of the EVFTA, both Vietnam and the EU have more trade opportunities but also face numerous challenges. Consequently, EU and Vietnam businesses need to have appropriate strategies to become more competitive. It is necessary for Vietnam and the EU to establish an open, transparent, non-discriminatory trading mechanism. The reality of world trade requires Vietnam and the EU to intensify cooperation on issues relating to supply chains, value chains, e-commerce, continued capacity building and regulatory coherence. This is the pre-requisite for the EU and Vietnam to continue their economic dynamism in the world trade system.

Human rights have been considered to be a significant component of the EU-Vietnam partnership. The EU values Vietnam's increased engagement with international human rights mechanisms, encouraging Vietnam to make the most of its membership in the United Nations Human Rights Council, and to have more visible achievements in human rights. Also, the EU welcomes Hanoi's willingness to increase Vietnamese engagement with United Nations Special Rapporteurs and Working Groups. However, the EU has often criticised Hanoi for human rights failures, for instance jailing political dissidents and blocking access to several websites and monitoring internet users' activities. ${ }^{36}$ The EU has considered trade negotiations as venues to promote human rights while Vietnam has preferred that human rights not be the centre of Vietnam-EU trade talks. ${ }^{37}$

The issue of human rights, if not addressed adequately, may negatively affect EUVietnam relations. The annual enhanced Human Rights Dialogue, in the framework of the EU-Vietnam Partnership and Cooperation Agreement has been a channel for Hanoi and Brussels to further exchange viewpoints and policy stance on human rights. Yet, more mechanisms will need to be established to enable Brussels and Hanoi to have more constructive and extensive discussions on the human rights situation in Vietnam. Such discussions may lead to practical measures for Vietnam to improve its human rights situation and to the EU's support for Vietnamese reform efforts.

It is undeniable that the EU and Vietnam have worked hard to strengthen socioeconomic, diplomatic and development cooperation in the last 27 years. How this relationship will evolve in the future will very much depend on how Hanoi and Brussels can address the two main issues: trade deficit and human rights. If there are still disagreements on trade conditions and human rights conditions, it may prevent Hanoi and Brussels from realising the objectives of their partnership and cooperation agreement.

\footnotetext{
$3^{36}$ Northwest Asian Weekly. 2010. Vietnam Published Human Rights Magazine. Accessed 14 November, 2017, <http://nwasianweekly.com/2010/o7/vietnam-publishes-human-rights-magazine/>.

37 See, WTO Center. 2017. Human Rights at Centre of Vietnam-EU Trade Talks. Accessed on 10 November, 2017, <http://wtocenter.vn/content/human-rights-centre-vietnam-eu-trade-talks >, and Daniela Sicurelli. 2015. (2015). 'The EU as a Promoter of Human Rights in Bilateral Trade Agreements: The Case of the Negotiations with Vietnam', Journal of Contemporary European Research. 11 (2), pp. 230-245.
} 


\section{Conclusion}

Vietnam has a long history of relations with European states, particularly with France, having been a French colony between 1887 and 1954. The origins of the contemporary economic and diplomatic relations between the European Union and Vietnam can be traced to 1986, when Vietnam, in order to diversify its foreign relations and integration into the world community, adopted the economic and political reform (Đổi Mới) laying the base for Vietnam to establish diplomatic relations with various countries regardless of political system and ideologies. Also, in 1986 the European Community sought to strengthen its economic and political integration with the Single European Act. Both Vietnam and the European Community saw these changes taking place in the late 198 os as an opportunity to move toward each other and work with each other for mutual benefits. During 27 years of Vietnam-EU relations, both sides have expanded cooperation from an initial humanitarian focus to different areas and issues. Many bilateral mechanisms and dialogues have been developed since 1990 allowing Vietnam and the EU to exchange views and enhance cooperation. With the new Partnership and Cooperation Agreement, Vietnam can play a more active role in its relations with the EU while the EU continues its commitment to cultivating a modern, broad-based and mutually-beneficial relationship with Vietnam. The EVFTA in particular is a milestone in Vietnam's relations with the EU. With a focus on trade, sustainable development, environmental protection, and labour rights, this trade deal promises to be a strong catalyst for Vietnam's fast economic growth and development. Significantly, the EVFTA might be used as a potential model for future free trade agreement negotiations between the EU and other ASEAN member states.

No doubt, the EU-Vietnam relations have developed significantly since 1990. The two periods (1990-2005 and 2006-2017) witnessed the concerted efforts made by both sides to become reliable partners. The EU-Vietnam friendship will continue to prosper, even as the EU is facing serious internal challenges (for example, Brexit, the Greek debt crisis, the Eurozone, the ongoing migrant and refugee flows as well as terrorism threats) and Vietnam has difficult issues to deal with (development gap, environmental degradation, food and water security, and rapid urbanisation). In spite of these challenges, and the issues of trade deficit as well as human rights concern, the future shape and directions of the EU-Vietnam partnership looks promising. Successive EU Commissioners and many members of the EU parliaments have long supported the EU's partnership with Vietnam, viewing it as significant to European economic dynamism and as a way to foster strong EU friends and trading partners in Asia. The EU and Vietnam share a dynamic diplomatic partnership on a wide range of foreign policy issues, and the EU-Vietnam trade and investment relations are extensive and mutually beneficial.

In the $21^{\text {st }}$ century, the EU-Vietnam partnership is uniquely valuable to both Vietnam and the EU. For Vietnam, integration and multilateralism are important as they will create prosperity. Hanoi's commitment to multiple partnerships, especially with the EU brings Vietnam more opportunities to realise its plan to become an industrialised country by 2020. Geopolitically and strategically, Vietnam is located in Asia, an active and dynamic region. Vietnam has made impressive socio-economic progress since its opening to the world in 1986. Now, with a growing middle class and with over 90 million consumers, a young work force, along with being one of the fastest growing economies in ASEAN with an average GDP growth rate of 6 percent, Vietnam is certainly a vibrant economy for EU businesses to invest in. How the EU-Vietnam 
partnership will evolve in the years ahead may have important strategic and economic implications for Asian security and prosperity. Indeed, a tighter and more coherent configuration of the EU-Vietnam relations will be more aligned with the need for further political and economic growth in the EU, Vietnam and the Asian region. 